\title{
How can anemia negatively influence gas exchange?
}

\author{
Roberta Pulcheri Ramos ${ }^{1}$
}

Tissues obtain energy primarily from oxygen. Adequate oxygen levels in the inhaled air and a preserved ventilation/ perfusion ratio $(\dot{V} / \mathrm{Q})$ are the major determinants of oxygen supply to the blood. However, peripheral supply depends on effective oxygen transport to the tissue mitochondria, a critical task that is performed by hemoglobin. Without hemoglobin, cardiac output would have to increase up to 20 times in order to meet resting metabolic demands, and this would certainly be incompatible with life. ${ }^{(1)}$

Arterial oxyhemoglobin saturation $\left(\mathrm{SaO}_{2}\right)$ represents the percentage of occupied oxygen binding sites on hemoglobin. In patients with chronic anemia, $\mathrm{SaO}_{2}$ is usually within the reference range, as is the amount of oxygen dissolved in the blood. However, the arterial oxygen content (which essentially depends on oxygen saturation levels and hemoglobin concentration) is reduced. This results in inadequate tissue supply, particularly when oxygen demand is increased, as occurs during exercise. Compensatory mechanisms include a hyperkinetic cardiovascular response and increased peripheral oxygen extraction. ${ }^{(2)}$ A reduction in mixed venous oxygen tension might contribute to arterial oxyhemoglobin desaturation during exercise, especially in patients with chronic cardiopulmonary disease.

In addition to the aforementioned mechanisms, the hemoglobin dissociation curve plays an important role in changes in gas exchange. Patients with sickle cell disease are of note in this context; it has been demonstrated that the hemoglobin dissociation curve shifts to the right in such patients. ${ }^{(3,4)}$ Although this constitutes a "protective" mechanism-given that it promotes the release of oxygen to the tissues-it can contribute to decreasing arterial

(A)

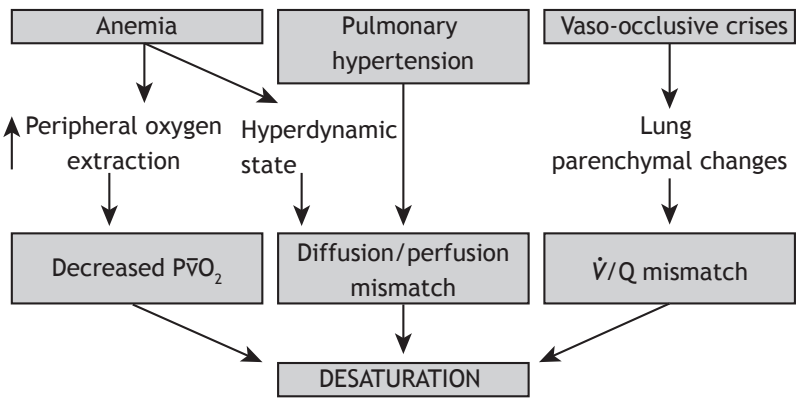

Contributing factors: rightward shift of the ODC,

increased $\mathrm{COHb}$ levels, and increased MetHb levels oxyhemoglobin levels in such patients, particularly during exercise, because hemoglobin $\mathrm{S}$ has low affinity for oxygen. In addition, the negative impact that lung parenchymal changes secondary to vaso-occlusive crises have on pulmonary gas exchange, particularly in adults with sickle cell disease, cannot be ignored. ${ }^{(5,6)}$ However, to date, few studies have examined lung function abnormalities in the early stages of the disease.

In the previous issue of the JBP, Vieira et al. ${ }^{(7)}$ evaluated children and adolescents with sickle cell disease using spirometry and the six-minute walk test. It is of note that changes in gas exchange during exercise were common in the study sample: $52 \%$ had a significant decrease in $\mathrm{SaO}_{2}$ as assessed by pulse oximetry $\left(\mathrm{SpO}_{2}\right)$ at the end of the six-minute walk test. This finding was common even in those with normal spirometry results.

In patients with sickle cell disease, the possibility of impairment in the pulmonary circulation is also of note. In a recent study conducted in Brazil, it was demonstrated that pulmonary hypertension $(\mathrm{PH})$ is a major complication of sickle cell disease. ${ }^{(8)}$ It was also demonstrated that patients with $\mathrm{PH}$ (including those with postcapillary $\mathrm{PH}$ ) have reduced exercise tolerance, despite having preserved or even increased cardiac output. In the study conducted by Vieira et al., ${ }^{(7)}$ the lack of echocardiographic evaluation constitutes a limitation that precludes the identification of other factors associated with desaturation. In patients with high-output $\mathrm{PH}$, increased pulmonary flow can lead to diffusion/perfusion mismatch enhanced by a rightward shift of the hemoglobin dissociation curve and associated $\dot{V} / \mathrm{Q}$ mismatch (Figure 1).

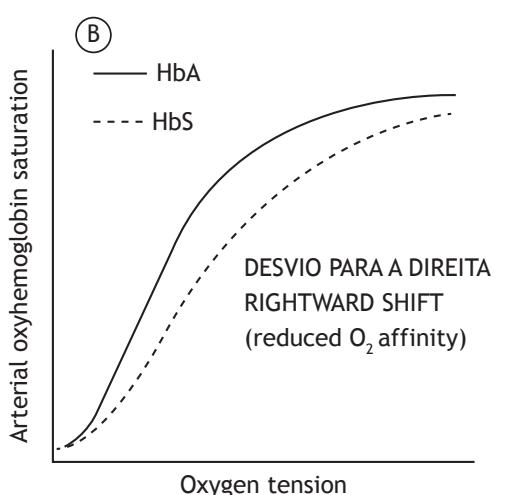

Oxygen tension

Figure 1. In A, factors potentially associated with desaturation in patients with sickle cell disease. In such patients, pulmonary hypertension generally presents as a hemodynamic state characterized by low pulmonary vascular resistance and high cardiac output, and is unlikely to contribute to decreasing $\mathrm{P}_{\bar{v}} \mathrm{O}_{2}$. In $\mathrm{B}$, graphical representation of the dissociation curves of hemoglobin $(\mathrm{Hb}) \mathrm{A}$ and $\mathrm{HbS}$. The rightward shift reflects reduced oxygen affinity. $\mathrm{P}_{\bar{V}} \mathrm{O}_{2}$ : mixed venous oxygen tension; $\dot{V} / \mathrm{Q}$ : ventilation/perfusion; ODC: oxyhemoglobin dissociation curve; $\mathrm{COHb}$ : carboxyhemoglobin; and MetHb: methemoglobin. 
In addition to the lack of echocardiographic evaluation, the aforementioned study has limitations such as the lack of lung volume measurements, DLCO measurement, and arterial blood gas analysis. However, the study is important because it shows the characteristics of sickle cell disease in a sample of patients in Brazil. It is of note that some of the results were inconsistent with the literature, the proportion of patients in whom $\mathrm{SpO}_{2}$ decreased during exercise being higher than those reported in previous studies. ${ }^{(9,10)}$ According to the authors, patients with sickle cell disease should be evaluated for lung function from childhood onward. Prospective cohort studies involving sickle cell disease patients are needed in order to identify possible prognostic implications.

\section{REFERENCES}

1. Neder JA, Nery LE, editors. Fisiologia clínica do exercício: teoria e prática. São Paulo: Artes Médicas; 2004

2. Pianosi P, D'Souza SJ, Charge TD, Béland MJ, Esseltine DW Coates AL. Cardiac output and oxygen delivery during exercise in sickle cell anemia. Am Rev Respir Dis. 1991;143(2):231-5. https://doi. org/10.1164/ajrccm/143.2.231

3. Becklake MR, Griffiths SB, McGregor M, Goldman HI, Schreve JP Oxygen dissociation curves in sickle cell anemia and in subjects with the sickle cell trait. J Clin Invest. 1955;34(5):751-5. https://doi. org/10.1172/JCl103129

4. Rackoff WR, Kunkel N, Silber JH, Asakura T, Ohene-Frempong K. Pulse oximetry and factors associated with hemoglobin oxygen desaturation in children with sickle cell disease. Blood 1993;81(12):3422-7.

5. Kassim AA, Payne AB, Rodeghier M, Macklin EA, Strunk RC, DeBaun MR. Low forced expiratory volume is associated with earlier death in sickle cell anemia. Blood. 2015;126(13):1544-50. https://doi. org/10.1182/blood-2015-05-644435

6. Knight-Madden JM, Forrester TS, Lewis NA, Greenough A. The impact of recurrent acute chest syndrome on the lung function of young adults with sickle cell disease. Lung. 2010;188(6):499-504 https://doi.org/10.1007/s00408-010-9255-2

7. Vieira AK, Alvim CG, Carneiro MC, Ibiapina CC. Pulmonary function in children and adolescents with sickle cell disease: have we paid proper attention to this problem? J Bras Pneumol. 2016;42(6):409 415. http://dx.doi.org/10.1590/s1806-37562016000000057 https:// doi.org/10.1590/s1806-37562016000000057

8. Fonseca GH, Souza R, Salemi VM, Jardim CV, Gualandro SF Pulmonary hypertension diagnosed by right heart catheterisation in sickle cell disease. Eur Respir J. 2012;39(1):112-8. https://doi. org/10.1183/09031936.00134410

9. Campbell A, Minniti CP, Nouraie M, Arteta M, Rana S, Onyekwere $\mathrm{O}$, et al. Prospective evaluation of haemoglobin oxygen saturation at rest and after exercise in paediatric sickle cell disease patients. $\mathrm{Br} J$ Haematol. 2009;147(3):352-9. https://doi.org/10.1111/j.13652141.2009.07854.x

10. Waltz $X$, Romana M, Lalanne-Mistrih ML, Machado RF, Lamarre $Y$, Tarer $\mathrm{V}$, et al. Hematologic and hemorheological determinants of resting and exercise-induced hemoglobin oxygen desaturation in children with sickle cell disease. Haematologica. 2013;98(7):1039-44 https://doi.org/10.3324/haematol.2013.083576 